\title{
PERANCANGAN SISTEM INFORMASI KINERJA PEGAWAI STUDI KASUS: BUMN KONTRUKSI
}

\author{
Ridha Hanafi \\ Telkom University \\ Jl. Telekomunikasi No 1 Terusan Buah Batu, Dayeuh Kolot Bandung, Jawa Barat 40257 \\ ridhanafi@gmail.com
}

\begin{abstract}
Abstrak
Dalam era kompetisi bisnis yang semakin tinggi dan tuntutan customer yang semakin meningkat, organisasi semakin dituntut untuk mencapai kinerja yang optimal dalam usahanya mencapai tujuan organisasi. Pencapaian kinerja organisasi sangat ditentukan oleh bagaimana organisasi mengoptimalisasi potensi sumber daya yang dimilikinya. Sumber daya utama yang dimiliki oleh organisasi dalam pencapaian tujuan organisasi adalah Sumber Daya Manusia (SDM). Agar SDM yang dimiliki oleh perusahaan dapat dimanfaatkan secara optimal dan fokus pada pencapaian tujuan organisasi maka perlu dilakukan proses manajemen kinerja pegawai yang baik. Secara strategis, kinerja pegawai harus dapat diselaraskan dengan kinerja organisasi untuk pencapaian tujuan strategis organisasi. Untuk mengakomodasi hal ini maka konsep Balanced Score Card sangat potensial untuk diakomodasi dan diimplementasikan. Pada level operasional, pengelolaan kinerja pegawai yang meliputi proses perencanaan kinerja (performance planning), pelaksanaan dan monitoring (performance tracking) dan penilaian kinerja (performance appraisal) harus dapat dilaksanakan secara komprehensif dan aplikatif sehingga realisasinya benar-benar sesuai dengan apa yang diharapkan organisasi.
\end{abstract}

Implementasi proses manajemen kinerja organisasi pada umumnya dan pegawai pada khususnya seperti yang dijelaskan tersebut, akan sangat sulit pelaksanaannya apabila masih dilakukan secara manual. Semakin kompleksnya parameter kinerja pegawai yang ingin dicapai, semakin besarnya jumlah pegawai, semakin dinamisnya perubahan bisnis dan semakin banyak kesibukan pekerjaan akan menyebabkan implementasi manajemen kinerja pegawai secara manual tidak efisien dan efektif untuk dilaksanakan karena proses bisnis yang kompleks, mekanisme pelaporan dan monitoring kinerja akan sangat memakan waktu dan sulit dilakukan. Implementasi sistem informasi manajemen kinerja pegawai merupakan suatu solusi yang potensial untuk diterapkan untuk menghadapi permasalahan tersebut. Apabila permasalahan tersebut dapat diatasi maka diharapkan pencapaian kinerja perusahaan dalam mencapai visi dan misinya dapat terealisasi. Berdasarkan hal tersebut, maka perlu dilakukan perancangan sistem aplikasi manajemen kinerja pegawai yang dapat memenuhi kebututuhan organisasi dan pegawai. Implementasi sistem ini diharapkan dapat mendukung berjalannya proses manajemen kinerja organisasi sehingga secara strategis tujuan organisasi dapat tercapai..

Kata kunci :

Manajemen Kinerja, Sistem Informasi Manajemen, Balanced Score Card, Manajemen Sumber Daya Manusia

\begin{abstract}
In an era of increasingly high business competition and customer demands, organizations are increasingly required to achieve optimal performance in an effort to achieve organizational goals. Achievement of organizational performance is largely determined by how the organization optimizes the potential of its resources. The main resource that the organization has in achieving its organizational goals is Human Resources (HR). In order for HR can be utilized optimally and focus on achieving organizational goals it is necessary to conduct an excellent employee performance management process. Strategically, employee performance must be aligned with organizational performance for the achievement of organizational strategic goals. To accommodate this concept, Balanced Score Card is very potential to be accommodated and implemented.
\end{abstract}


At the operational level, employee performance management that includes performance planning process, performance monitoring and performance appraisal must be implemented comprehensively and applicable so that the realization is exactly what the organization expects.

Implementation of the organization's performance management process in general and employees in particular as described, will be very difficult if it is still done manually. The more complex the performance parameters of employees to be achieved, the greater the number of employees, the more dynamic the business changes and the more busy work will lead to implementation of employee performance management manually inefficient and ineffective. This is because of complex business processes, reporting mechanisms and performance monitoring will be very time consuming and difficult to do. Implementation of employee performance management information system is a potential solution to be applied to face the problem. If the problem can be solved, it is expected that the achievement of the company's performance in achieving its vision and mission can be realized. Based on this, it is necessary to design an employee performance management application system that can meet the needs of the organization and employees. Implementation of this system is expected to support the running of organizational performance management process so that the strategic objectives of the organization can be achieved.

Keywords :

Performance Management, Management Information System, Balanced Score Card, Human Resources Management

\section{Pendahuluan}

Persaingan bisnis dan kebutuhan pelanggan yang semakin meningkat menuntut perusahaan untuk selalu bisa mengikuti perubahan tuntutan bisnis yang dinamis secara cepat, tepat dan responsif. Untuk dapat bergerak dan melakukan pengambilan keputusan secara cepat, tepat dan responsif, perusahaan tidak bisa lagi menggunakan cara-cara konvensional yang selama ini dilakukan. Diperlukan inovasi yang dapat membuat kebutuhan bisnis yang dinamis tersebut dapat selalu dipenuhi sesuai dengan waktu dan kondisinya. Potensi inovasi yang dapat dilakukan untuk memenuhi kebutuhan bisnis yang dinamis tersebut sangat mungkin terealisasi dengan dukungan sistem dan teknologi informasi. Implementasi sistem dan teknologi informasi yang tepat guna memungkinkan perusahaan untuk selalu dapat bersikap adaptif terhadap perubahan dan kebutuhan yang ada serta sehingga dapat melakukan proses pengambilan keputusan secara maksimal.

Sumber Daya Manusia (SDM) merupakan salah satu sumber daya terpenting perusahaan yang akan menentukan arah kesuksesan perusahaan. Kinerja perusahaan dalam pencapaian visi dan misinya hanya dapat terealisasi apabila didukung oleh SDM yang memiliki kompetensi dan memberikan kinerja yang optimal bagi perusahaan. Seiring dengan perkembangan bisnis dan kompetisi yang semakin tinggi, tuntutan target kinerja perusahaan akan tinggi dan semakin bersifat dinamis mengikuti perubahan strategi bisnis perusahaan. Oleh karena itu perlu adanya suatu mekanisme pengelolaan manajemen kinerja perusahaan yang dapat mengikuti arahan perkembangan perusahaan yang dapat dikelola secara terencana, terukur, jelas, fleksibel, realistis dan dapat diimplementasikan secara menyeluruh di seluruh unit bisnis perusahaan mulai dari level organisasi tertinggi sampai terendah. Implementasi manajemen kinerja perusahaan harus dapat di cascading dari level tertinggi perusahaan sampai dengan level terendah dan harus dapat melibatkan peran serta aktif seluruh unit kerja yang ada beserta pegawai yang ada di dalamnya. Kesuksesan pencapaian kinerja pegawai akan menentukan berhasil tidaknya perusahaan mencapai kinerja yang diharapkan dalam pencapaian visi dan misi perusahaan.

Implementasi manajemen kinerja perusahaan pada umumnya dan pegawai pada khususnya seperti yang dijelaskan tersebut, akan sangat sulit pelaksanaannya apabila masih dilakukan secara manual. Semakin kompleksnya parameter kinerja pegawai yang ingin dicapai, semakin besarnya jumlah pegawai, semakin dinamisnya perubahan bisnis dan semakin banyak kesibukan pekerjaan akan menyebabkan implementasi manajemen kinerja pegawai secara manual tidak efisien dan efektif untuk dilaksanakan karena proses bisnis yang kompleks, mekanisme pelaporan dan monitoring kinerja akan sangat memakan waktu dan sulit dilakukan.

Implementasi sistem informasi manajemen kinerja pegawai merupakan suatu solusi yang potensial untuk diterapkan untuk menghadapi 
permasalahan tersebut. Pengembangan sistem informasi manajemen kinerja pegawai dikembangkan berdasarkan best practices yang ada seperti dengan memanfaatkan konsep Balanced Score Card namun juga disesuaikan dengan kebutuhan spesifik perusahaan. Identifikasi kebutuhan spesifik perusahaan diperoleh berdasarkan hasil observasi dan wawancara dengan pihak pengambil keputusan di lingkungan perusahaan khusunya terkait manajemen kepegawaian. Dengan berhasilnya implementasi sistem informasi manajemen kinerja pegawai diharapkan dapat membantu mempermudah implementasi manajemen kinerja perusahaan secara praktis di lapangan sehingga untuk jangka panjang, pencapaian kinerja perusahaan dalam mencapai visi dan misinya dapat terealisasi.

\section{I.1 Metodologi}

Dalam melakukan penelitian ini, supaya lebih terarah, terstruktur dan menghasilkan hasil yang lebih valid, metode penelitian yang dilakukan dapat dilihat pada gambar sebagai berikut :

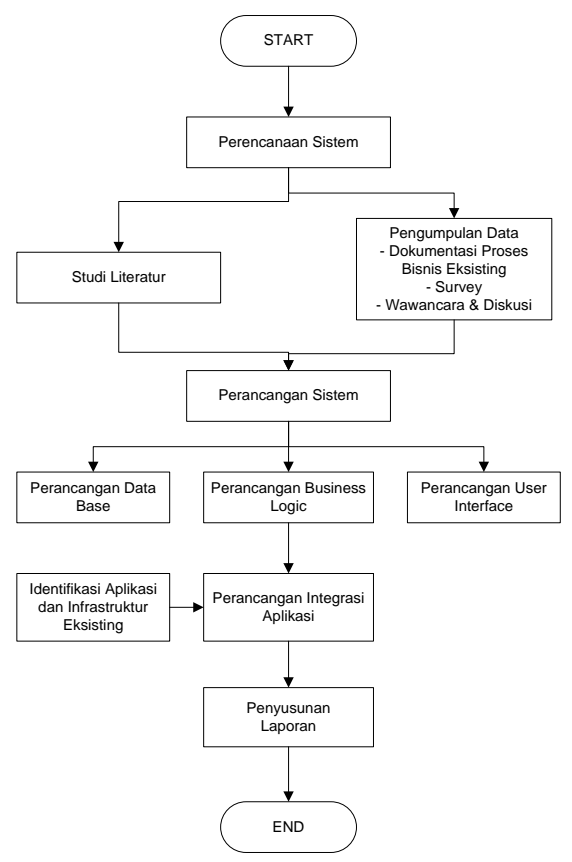

Gambar 1 Metodologi Penelitian

Penelitian dimulai dengan tahapan perencanaan system, dimana pada tahapan ini dilakukan identifikasi tujuan dan ruang lingkup pengembangan system, identifikasi permasalahan dan perencanaan pengembangan system. Untuk kebutuhan data dan informasi yang dibutuhkan untuk desain perancangan sistem dilakukan studi literature untuk mendapatkan referensi konsep manajemen kinerja, balanced score card serta konsep lainnya yang dapat digunakan dalam pengembangan system serta pengumpulan data di organisasi perusahaan, dengan cara : pengumpulan dokumentasi proses bisnis dan system terkait, survey langsung ke lokasi dan melakukan wawancara dan diskusi dengan pihak terkait yang memiliki otorisasi untuk penyusunan dan pengambilan keputusan terkait proses manajemen kinerka di organisasi.

Setelah sumber data dan informasi yang dibutuhkan tersedia, maka dilakukan proses perancangan atau desain system. Perancangan system dilakukan secara garis besar meliputi perancangan business logic system, database dan user interface. Pada penelitian ini juga akan dilakukan desain integrasi aplikasi antara aplikasi/ modul pengelolaan kinerja pegawai dengan aplikasi/ modul lain yang terkait dalam organisasi. Keseluruhan desain perancangan system akan didokumentasikan dalam laporan final penelitian.

\section{KAJIAN LITERATUR}

\section{II.1 Manajemen Kinerja}

Manajemen merupakan sebuah proses perencanaan, pengorganisasian, pengkoordinasian, dan pengontrolan sumber daya untuk mencapai sasaran secara efektif dan efesien. Efektif berarti bahwa tujuan dapat dicapai sesuai dengan perencanaan, sementara efisien berarti bahwa tugas yang ada dilaksanakan secara benar, terorganisir, dan sesuai dengan jadwal (Griffith, 1995). Manajemen adalah proses yang mencakup perencanaan, pengorganisasian, pengarahan dan pengendalian terhadap penggunaan sumber daya yang dimiliki, baik manusia dan material untuk mencapai tujuan (Schermerhorn Jr, 2011)

Definisi dari kinerja atau performa adalah sebagai berikut: Kinerja merupakan suatu fungsi dari motivasi dan kemampuan. Untuk menyelesaikan tugas atau pekerjaan seseorang harus memiliki derajat kesediaan dan tingkat kemampuan tertentu. Kesediaan dan ketrampilan seseorang tidaklah cukup efektif untuk mengerjakan sesuatu tanpa pemahaman yang jelas tentang apa yang akan dikerjakan dan bagaimana mengerjakannya (Hersey and Blanchard, 1993). Kinerja merujuk kepada tingkat keberhasilan dalam melaksanakan tugas serta kemampuan untuk mencapai tujuan yang telah ditetapkan. Kinerja dinyatakan baik dan sukses jika tujuan yang

Ridha Hanafi 
diinginkan dapat tercapai dengan baik (Donelly, Gibson and Ivancevich, 1994). Dengan demikian, kinerja adalah kesediaan seseorang atau kelompok orang untuk melakukan sesuatu kegiatan dan menyempurnakannya sesuai dengan tanggung jawabnya dengan hasil seperti yang diharapkan.

Berdasarkan pengertian tersebut dapat dirumuskan bahwa pada dasarnya manajemen kinerja merupakan proses bisnis, sarana dan gaya manajemen dalam mengelola sumberdaya organisasi yang berorientasi pada kinerja yang melakukan proses komunikasi secara terbuka dan berkelanjutan dengan menciptakan visi bersama dan pendekatan strategis serta terpadu sebagai kekuatan pendorong untuk mencapai tujuan organisasi.

\section{II.1.1 Manfaat Implementasi Manajemen Kinerja}

Setiap organisasi yang dibentuk pasti akan memiliki tujuan. Pencapaian tujuan organisasi menunjukkan hasil kerja/prestasi organsisasi dan menunjukkan kinerja organisasi. Hasil kerja organisasi diperoleh dari serangkaian aktivitas yang dijalankan. Aktivitas tersebut dapat berupa pengelolaan sumberdaya organisasi maupun proses pelaksanaan kerja yang diperlukan untuk mencapai tujuan organisasi. Untuk menjamin agar aktivitas tersebut dapat mencapai hasil yang diharapkan, diperlukan upaya manajemen dalam pelaksanaan aktivitasnya.

Implementasi manajemen kinerja dalam perusahaan selain dapat memberikan manfaat kepada organisasi saja tetapi juga kepada manajer dan individu. Bagi organisasi, manfaat manajemen kinerja adalah menyesuaikan tujuan organisasi dengan tujuan tim dan individu, memperbaiki kinerja , memotivasi pekerja, meningkatkan komitmen, mendukung nilainilai inti, memperbaiki proses pelatihan dan pengembangan, meningkatkan dasar ketrampilan, mengusahakan perbaikan dan pengembangan berkelanjutan, mengusahakan basis perencanaan karier, membantu menahan pekerja terampil agar tidak pindah, mendukung inisiatif kualitas total dan pelayanan pelanggan, mendukung program perubahan budaya. Bagi manajer, manfaat manajemen kinerja antara lain: mengupayakan klarifikasi kinerja dan harapan perilaku, menawarkan peluang menggunakan waktu secara berkualitas, memperbaiki kinerja tim dan individual, mengusahakan penghargaan nonfinansial pada staf, membantu karyawan yang kinerjanya rendah, digunakan untuk mengembangkan individu, mendukung kepemimpinan, proses motivasi dan pengembangan tim, mengusahakan kerangka kerja untuk meninjau ulang kinerja dan tingkat kompensasi. Bagi individu, manfaat manajemen kinerja antara lain dalam bentuk: memperjelas peran dan tujuan, mendorong dan mendukung untuk tampil baik, membantu pengembangan kemampuan dan kinerja, peluang menggunakan waktu secara berkualitas, dasar objektivitas dan kejujuran untuk mengukur kinerja, dan memformulasi tujuan dan rencana perbaikan cara bekerja dikelola dan dijalankan.

\section{II.1.2 Model Manajemen Kinerja}

Menurut Pramuhanto (2005), model manajemen kinerja secara garis besar dapat digambarkan sebagai berikut :

Proses Manajemen Kinerja merupakan suatu siklus yang dijalankan oleh organisasi secara rutin dalam periode waktu tertentu yang disesuaikan dengan target pencapaikan tujuan organisasi. Siklus proses manajemen kinerja organisasi terdiri dari :

\section{Performance Planning}

Merupakan proses awal siklus kinerja dengan melakukan perencanaan kinerja yang dilakukan oleh pegawai dengan fokus utama:

- Membuat target kinerja sesuai dengan rencana bisnis

- Kesepakatan antara Atasan dan Bawahan agar mendapat komitmen

2. Performance Tracking

Merupakan proses pelaksanaan pencapaian kinerja pegawai berdasarkan rencana target yang sudah ditetapkan dalam Performance Planning. Fokus pada proses ini adalah :

- $\quad$ Proses diskusi yang berkesinambungan untuk mendukung pencapaian target

- $\quad$ Proses monitor progress pencapaian kinerja

- $\quad$ Proses pemberian umpan balik terhadap hasil kinerja yang diperoleh

3. Performance Appraisal
Ridha Hanafi

Jurnal Ilmiah Teknologi Informasi Terapan

Volume III, No 3, 30 Agustus 2017 
Merupakan proses penilaian yang dilakukanberdasarkan hasil pencapaian kinerja yang sudah dilakukan. Fokus pada proses ini adalah :

- Umpan balik terhadap kinerja keseluruhan

- Peninjauan realisasi terhadap rencana

- Pemberian rating kinerja

- Identifikasi kebutuhan pengembangan

\section{KonSEP BALANCED SCORE CARD}

Balanced Score Card (BSC) adalah pendekatan terhadap strategi manajemen yang dikembangkan oleh Robert Kaplan (Harvard Business School) and David Norton pada awal tahun 1990. BSC berasal dari dua kata yaitu balanced (berimbang) dan scorecard (kartu skor). Balanced (berimbang) berarti adanya keseimbangan antara kinerja keuangan dan nonkeuangan, kinerja jangka pendek dan jangka panjang, antara kinerja yang bersifat internal dan eksternal. Sedangkan scorecard (kartu skor) yaitu kartu yang digunakan untuk mencatat skor performance seseorang. Kartu skor juga dapat digunakan untuk merencanakan skor yang hendak diwujudkan oleh seseorang di masa depan. BSC adalah suatu mekanisme sistem manajemen yang mampu menerjemahkan visi dan strategi organisasi ke dalam tindakan nyata di lapangan. BSC adalah salah satu alat manajemen yang telah terbukti membantu banyak perusahaan dalam mengimplementasikan strategi bisnis organisasi. BSC dapat mendukung manajemen kinerja organisasi modern dalam merealisasikan strategi bisnis menjadi indikator kinerja yang bersifat kuantitatif, sehingga memudahkan perencanaan, monitoring dan penilaian kinerja (Kaplan, 1996)

Dalam konsep BSC, ditetapkan beberapa kriteria yang merupakan penjabaran dari apa yang menjadi misi dan strategi perusahaan dalam jangka panjang. Kriteria tersebut digolongkan menjadi empat perspektif yang berbeda yaitu :

1. Perspektif keuangan (financial) yaitu bagaimana organisasi berorientasi pada aspek keuangan bagi seluruh stakeholder.

2. Perspektif pelanggan (customer satisfaction) adalah bagaimana organisasi bisa menjadi supplier utama yang paling bernilai bagi para pelanggan.
3. Perspektif proses bisnis internal (internal business process), yakni proses bisnis apa saja yang terbaik yang harus dilakukan organisasi, dalam jangka panjang maupun jangka pendek untuk mencapai tujuan finansial dan kepuasan pelanggan.

4. Perspektif pertumbuhan dan pembelajaran (learning \& growth) ialah bagaimana organisasi dapat meningkatkan dan menciptakan value secara terus menerus,terutama dalam hubungannya dengan kemampuan dan motivasi pegawai.

Dalam BSC, keempat persektif tersebut menjadi satu kesatuan yang tidak dapat dipisahkan. Keempat perspektif tersebut juga merupakan indikator pengukuran kinerja yang saling melengkapi dan saling memiliki hubungan sebab akibat (Kaplan, 1996)

\section{III.1 Perancangan Sistem}

Perancangan sistem informasi dilakukan dengan menggunakan metoda System Development Lyfe Cycle (SDLC) (Pressman, 2014). SDLC adalah keseluruhan proses dalam membangun sistem melalui beberapa tahapan yang meliputi :

1. Perencanaan Sistem (Systems Planning),

Tahapan ini menekankan pada aspek studi kelayakan pengembangan sistem (feasibility study). Aktivitas-aktivitas yang dilakukan meliputi :

- Pembentukan dan konsolidasi tim pengembang.

- Mendefinisikan tujuan dan ruang lingkup pengembangan.

- Mengidentifikasi apakah masalah-masalah yang ada bisa diselesaikan melalui pengembangan sistem.

- Menentukan dan evaluasi strategi yang akan digunakan dalam pengembangan sistem.

- Penentuan prioritas teknologi dan pemilihan aplikasi.

2. Analisis Sistem (Systems Analysis)

Analisa sistem adalah tahap di mana dilakukan beberapa aktivitas berikut:

- Melakukan studi literatur untuk menemukan suatu kasus yang bisa ditangani oleh sistem.

- Brainstorming dalam tim pengembang mengenai kasus mana yang paling tepat dimodelkan dengan sistem. 
- Mengklasifikasikan masalah, peluang, dan solusi yang mungkin diterapkan untuk kasus tersebut.

- Analisa kebutuhan pada sistem dan membuat batasan sistem.

- Mendefinisikan kebutuhan sistem.

3. Perancangan Sistem (Systems Design)

Pada tahap ini, features dan operasi-operasi pada sistem dideskripsikan secara detail. Aktivitas-aktivitas yang dilakukan adalah:

- Menganalisa interaksi obyek dan fungsi pada sistem.

- Menganalisa data dan membuat skema database.

- Merancang user interface.

4. Implementasi Sistem

(Systems Implementation)

Pada tahap ini dilakukan implementasi rancangan dari tahap-tahap sebelumnya dan melakukan uji coba. Dalam implementasi, dilakukan aktivitas-aktivitas sebagai berikut:

- Pembuatan database sesuai skema rancangan.

- Pembuatan aplikasi berdasarkan desain sistem.

- Pengujian dan perbaikan aplikasi (debugging).

5. Pemeliharaan Sistem (Systems Maintenance)

Dilakukan oleh admin yang ditunjuk untuk menjaga sistem tetap mampu beroperasi secara benar melalui kemampuan sistem dalam mengadaptasikan diri sesuai dengan kebutuhan

\section{Analisis dan Perancangan}

Secara garis besar perancangan sistem dilakukan berdasarkan kebutuhan proses pengelolaan kinerja pegawai perusahaan yang meliputi : meliputi proses perencanaan kinerja (performance planning), pelaksanaan dan monitoring (performance tracking) dan penilaian kinerja (performance appraisal). Keseluruhan proses tersebut disesuaikan dengan kebutuhan secara spesifik yang ada pada perusahaan. Adapun untuk perancangan sistem informasi yang dilakukan meliputi : Identifikasi kebutuhan sistem, Perancangan aliran proses sistem, perancangan data base, perancangan antar muka (user interface system) serta perancangan integrasi aplikasi terkait

\section{IV.1 Identifikasi Kebutuhan Sistem \& Perancangan Aliran Proses}

Identifikasi kebutuhan sistem dilakukan dengan metoda observasi dan wawancara. Secara umum sesuai dengan kebutuhan sistem akan dikembangkan untuk mengakomodasi proses pengelolaan kinerja pegawai perusahaan yang meliputi : meliputi proses perencanaan kinerja (performance planning), pelaksanaan dan monitoring (performance tracking) dan penilaian kinerja (performance appraisal).

Skema hubungan implementasi konsep BSC pada proses manajemen kinerja organisasi dapat digambarkan sebagai berikut :

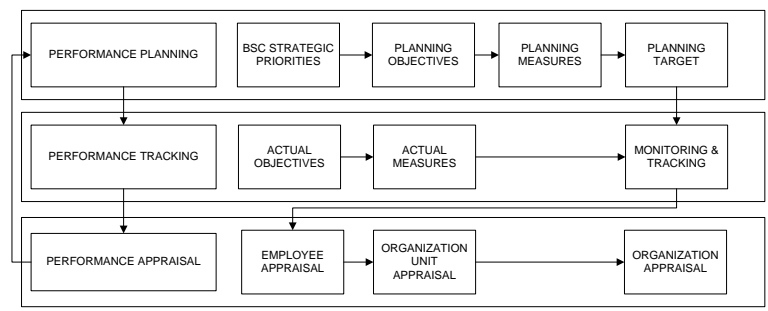

Gambar 2 Skema proses manajemen kinerja organisasi dan implementasi konsep BSC

\section{IV.1.1 Perencanaan Kinerja (Performance Planning)}

Perencanaan kinerja pegawai dilakukan berdasarkan penentuan Key Performance Indicator (KPI) Unit kerja yang dilakukan dengan melalui mekanisme cascading secara top-down dari level tertinggi perusahaan sampai terbawah. Sesuai dengan gambar 2, pertama kali pada level perusahaan ditentukan prioritas strategi (strategic priorities) berdasarkan parameter BSC. Penentuan (KPI) level perusahaan menggunakan model KPI Balanced Score Card (BSC) meliputi : Financial, Customer Satisfaction, Internal Business Process, Learning \& Growth

Selanjutnya prioritas strategi tersebut diturunkan kedalam beberapa objective yang disesuaikan dengan unit kerja perusahaan. Penentuan KPI individu pemegang jabatan dapat ditentukan per masingmasing unit kerja berdasarkan arahan pimpinan unit kerja yang bersangkutan sesuai dengan objective unit kerja tersebut. Proses perencanaan kinerja pegawai dilakukan pada awal tahun berjalan sampai dengan batas waktu yang ditentukan (umumnya sampai dengan bulan ke-3) 
Aliran Proses Perencanaan Kinerja pada sistem secara detail adalah sebagai berikut :

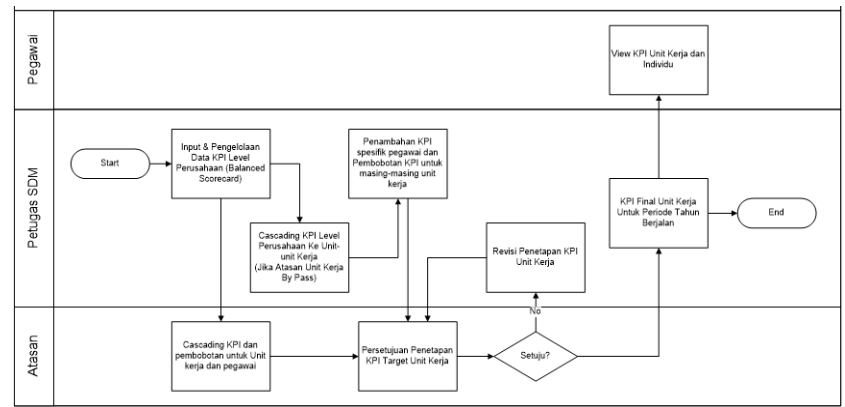

Gambar 3 Aliran Proses Perencanaan Kinerja

Adapun list kebutuhan (Requirement) System dapat dilihat pada Tabel sebagai berikut :

Tabel 1. Kebutuhan Sistem - Perencanaan Kinerja

\begin{tabular}{|c|c|}
\hline No & "Kebutuhan Sistem \\
\hline 1 & $\begin{array}{l}\text { Mampu melakukan pengelolaan KPI level perusahaan } \\
\text { (Balanced Scorecard) }\end{array}$ \\
\hline 2 & $\begin{array}{l}\text { Mampu melakukan cascading KPI level perusahaan } \\
\text { ke unit dibawahnya (unit-unit kerja), mulai dari level } \\
\text { direksi, GM, deputi, manajer dan Asman }\end{array}$ \\
\hline 3 & $\begin{array}{l}\text { Mampu melakukan persetujuan penetapan KPI yang } \\
\text { akan dicapai oleh unit kerja dalam perioda tahun } \\
\text { tertentu }\end{array}$ \\
\hline 4 & $\begin{array}{l}\text { Mampu melakukan cascading KPI level unit kerja } \\
\text { kepada masing-masing pegawai }\end{array}$ \\
\hline 5 & $\begin{array}{l}\text { Mampu melakukan setting KPI individu berdasarkan } \\
\text { tata nilai perusahaan untuk masing-masing unit kerja }\end{array}$ \\
\hline 6 & $\begin{array}{l}\text { Mampu melakukan cascading KPI individu mulai } \\
\text { dari level GM kebawah }\end{array}$ \\
\hline 7 & $\begin{array}{l}\text { Mampu melakukan input data KPI spesifik untuk } \\
\text { masing-masing indivu (pegawai) }\end{array}$ \\
\hline 8 & $\begin{array}{l}\text { Mampu melakukan pembobotan KPI masing-masing } \\
\text { pegawai antara KPI Individu dan KPI berdasarkan } \\
\text { cascading unit kerja }\end{array}$ \\
\hline 9 & $\begin{array}{l}\text { Mampu melakukan proses persetujuan KPI masing- } \\
\text { masing individu (Pegawai) }\end{array}$ \\
\hline
\end{tabular}

\section{IV.1.2 Pelaksanaan dan monitoring - (Performance Tracking) dan Penilaian Kinerja (Performance Appraisal).}

Proses pelaksanaan dan monitoring kinerja pegawai dilaksanakan setelah proses perencanaan kinerja selesai dilakukan dan sudah disetujui. Proses ini dilakukan sepanjang tahun berjalan sampai dengan batas waktu untuk penilaian kinerja yang umumnya dilakukan pada akhir tahun berjalan. Sesuai dengan Gambar 4, setiap pegawai dapat melaporkan pencapaian kinerjanya setiap saat selama periode pelaksanaan kinerja. Atasan pegawai yang bersangkutan dapat melakukan monitoring pencapaian kinerja dan dapat memberikan feedback atas apa yang sudah dicapai oleh bawahannya.

Proses penilaian kinerja dapat dilakukan setiap saat oleh atasan setiapkali bawahan melakukan pelaporan pencapaian kinerja. Proses penilaian ini berjalan simultan selama pelaksanaan dan monitoring kinerja tahunan. Pada akhir tahun atau periode yang ditentukan, proses penilaian kinerja ini dapat difinalisasi untuk mendapatkan nilai akhir pencapaian kinerja pegawai. Pencapaian kinerja pegawai akan berkontribusi pada pencapaian kinerja unit kerja. Pencapaian kinerja unit kerja akan berkontribusi pada pencapaian kinerja perusahaan.

Aliran proses pelaksanaan dan monitoring (Performance Tracking) dan penilaian kinerja (Performance Appraisal) pada sistem adalah sebagai berikut :

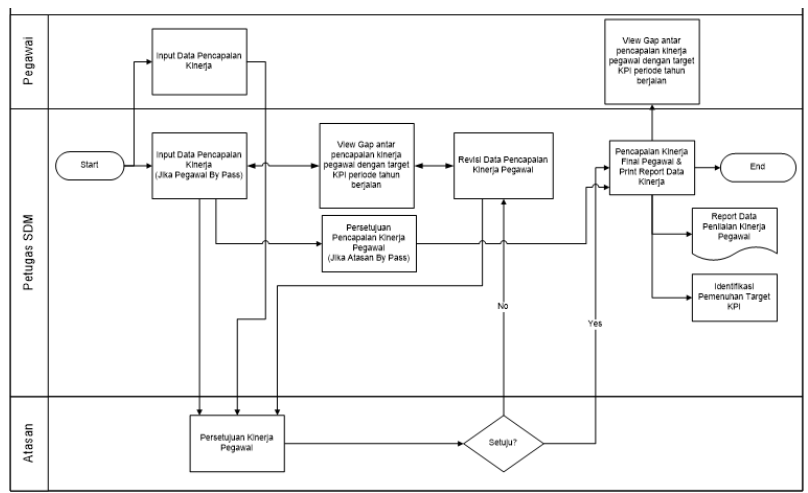

Gambar 4 Aliran Proses Pelaksanaan, Monitoring dan Penilaian Kinerja

Adapun list kebutuhan (Requirement) system dapat dilihat pada Tabel sebagai berikut :

Tabel 2. Kebutuhan Sistem - Pelaksanaan, Monitoring dan Penilaian Kinerja

\begin{tabular}{ll}
\hline \hline No & Kebutuhan Sistem \\
\hline \hline 1 & $\begin{array}{l}\text { Mampu melakukan identifikasi KPI target yang harus } \\
\text { dicapai oleh masing-masing pegawai }\end{array}$ \\
2 & $\begin{array}{l}\text { Mampu melakukan input data pencapaian KPI secara } \\
\text { kuantitatif untuk masing-masing pegawai baik oleh } \\
\text { pegawai sendiri ataupun petugas kepegawaian secara }\end{array}$ \\
& $\begin{array}{l}\text { online } \\
\text { Mampu melakukan perhitungan secara otomatis } \\
\text { pencapaian KPI dan membandingkannya dengan KPI } \\
\text { rencana (target) }\end{array}$
\end{tabular}

Ridha Hanafi

Jurnal Ilmiah Teknologi Informasi Terapan

Volume III, No 3, 30 Agustus 2017 
$4 \quad$ Mampu melakukan monitoring pencapaian KPI untuk masing-masing pegawai secara real time

5 Mampu melakukan persetujuan pencapaian KPI pegawai secara online

6 Mampu melakukan upload data penunjang pencapaian KPI

7 Mampu melakukan identifikasi KPI target yang harus dicapai oleh masing-masing pegawai

8 Mampu melakukan input data pencapaian KPI secara kuantitatif untuk masing-masing pegawai baik oleh pegawwai sendiri ataupun petugas kepegawaian secara online

9 Mampu melakukan perhitungan secara otomatis pencapaian KPI dan membandingkannya dengan KPI rencana (target)

10 Mampu melakukan finalisasi perhitungan kinerja pegawai dan persetujuan online oleh atasan

11 Mampu melakukan rekapitulasi nilai kinerja pegawai untuk menentukan kinerja unit kerja dan seterusnya sehingga level perusahaan

\section{IV.2 Perancangan Database}

Perancangan database yang dilakukan meliputi penyusunan Conceptual Data Model (CDM) dan Physical Data Model (PDM)

1. Conceptual Data Model (CDM)

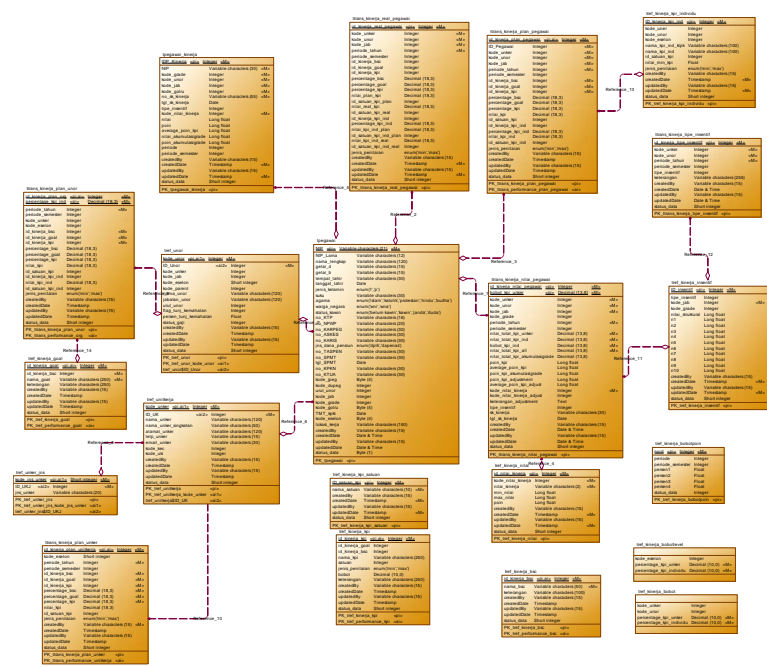

Gambar 5 Conceptual Data Model (CDM)

2. Physical Data Model (PDM)

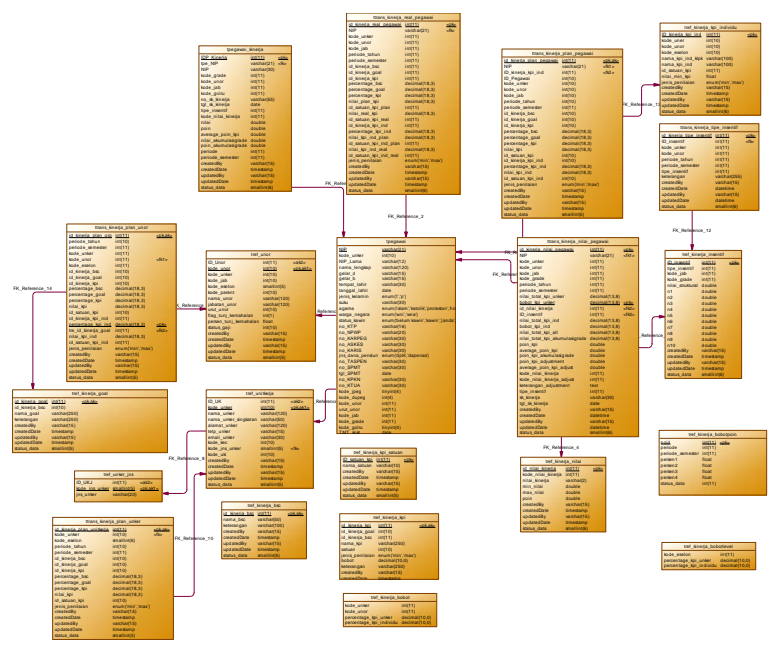

Gambar 6 Physical Data Model (PDM)

\section{IV.3 Perancangan Antar Muka (User Interface)}

a. Level Unit Organisasi :

Display tampilan :

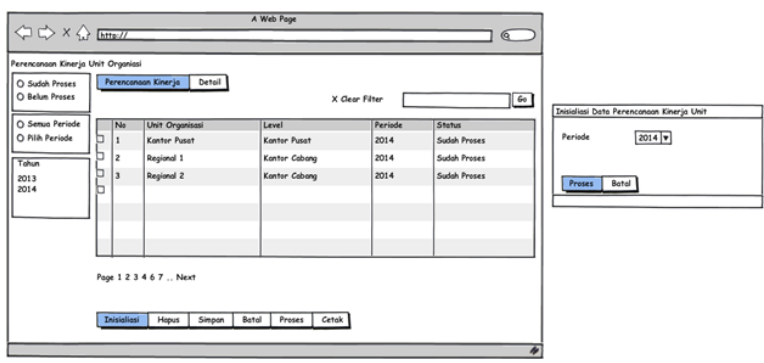

Gambar 7 Modul Kinerja Unit Organisasi

Display tampilan detail :

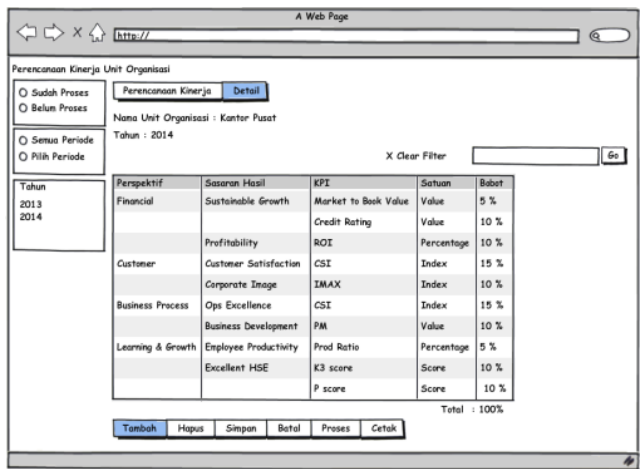

Gambar 8 Modul Kinerja Unit Organisasi Detail

Ridha Hanafi 
Display tampilan sbb :

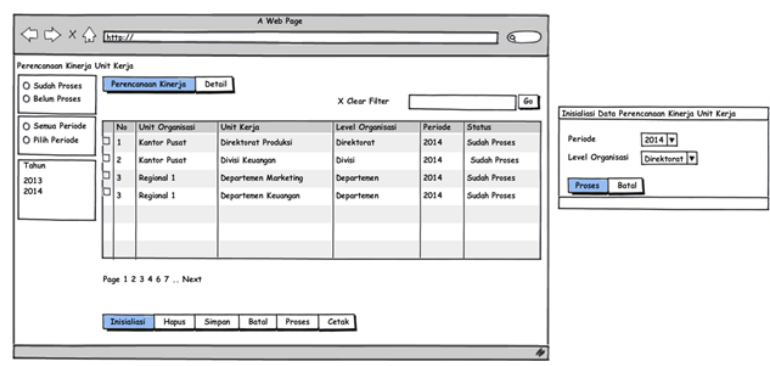

Gambar 9 Modul Kinerja Organisasi

Display tampilan detail

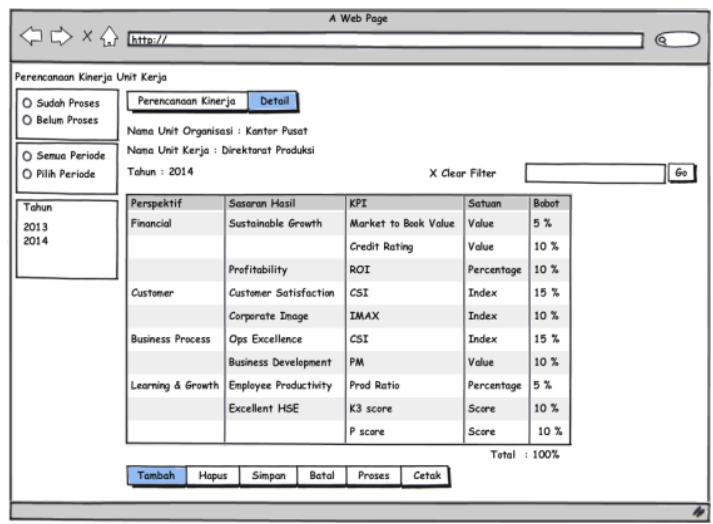

Gambar 10 Modul Kinerja Organisasi Detail

c. Level Organisasi - Jabatan

Display tampilan sbb :

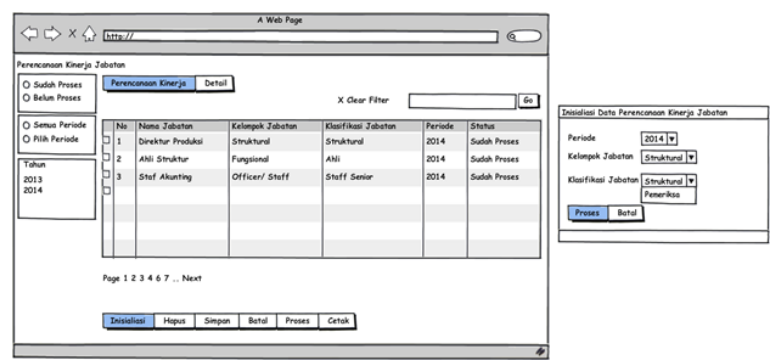

Gambar 11 Modul Kinerja Jabatan

Display tampilan detail

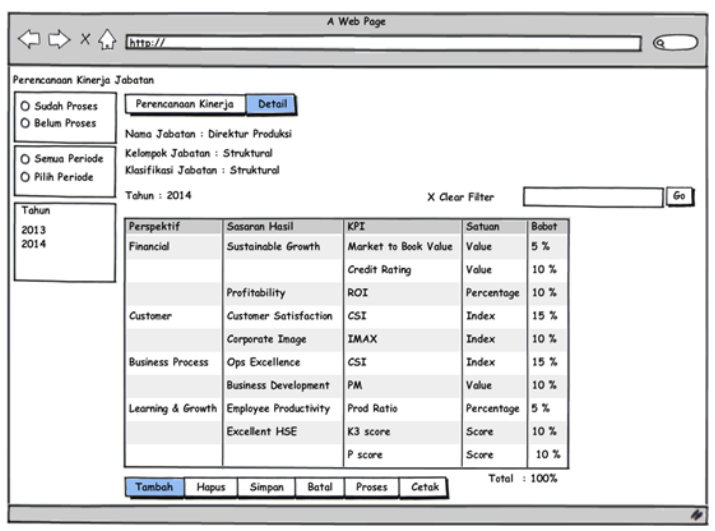

Gambar 12 Modul Kinerja Jabatan Detail

d. Level Pegawai :

Display tampilan sbb :

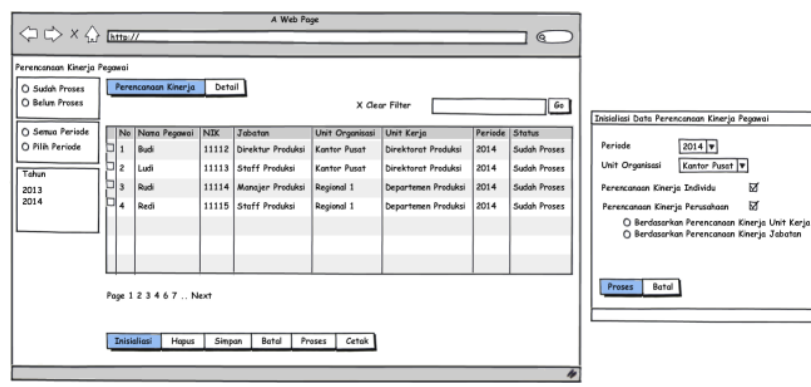

Gambar 13 Modul Kinerja Pegawai

Display tampilan detail :

Perencanaan Kinerja Perusahaan (Unit Kerja)

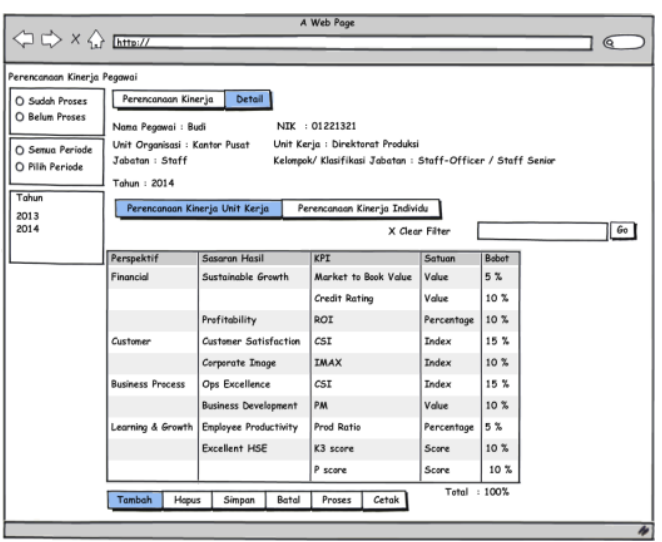

Gambar 14 Perencanaan Kinerja Perusahaan (Unit Kerja)

Perencanaan Kinerja Individu
Ridha Hanafi

Jurnal Ilmiah Teknologi Informasi Terapan

Volume III, No 3, 30 Agustus 2017 


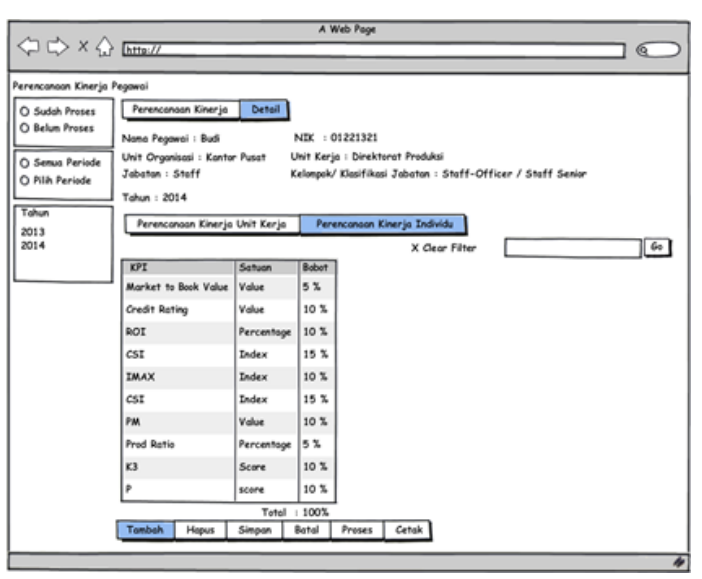

Gambar 13 Perencanaan Kinerja Individu

\section{IV.4 Perancangan Integrasi Aplikasi}

Aplikasi Sistem Informasi Kinerja Pegawai akan memiliki keterkaitan proses bisnis dengan beberapa aplikasi lainnya terutama aplikasi yang mengelola Master Pegawai sebagai sumber data pegawai dan aplikasi pengelolaan kompetensi pegawai. Output dari hasil integrasi sistem informasi kinerja dan kompetensi pegawai akan dapat menghasilkan Talent Pool System yang dapat digunakan sebagai sumber informasi untuk melakukan review pengembangan pegawai ke masa depan.Selain itu data kinerja pegawai juga dapat ditampilkan pada Portal Intranet Perusahaan.

Display Application Communication Diagram adalah sebagai berikut :

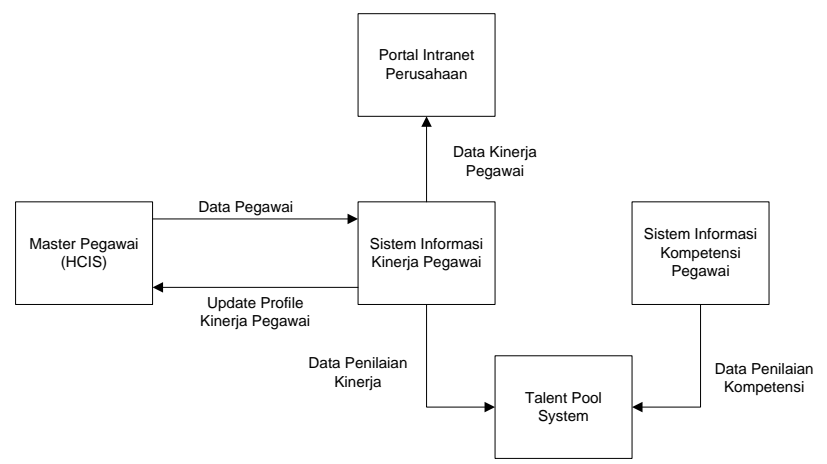

Gambar 15 Application Communication Diagram

Untuk implementasi teknologi interface integrasi dapat dilihat pada table sebagai berikut :

Tabel 3. Interface Catalog

\begin{tabular}{|l|l|l|l|}
\hline No & $\begin{array}{l}\text { Provider } \\
\text { Application }\end{array}$ & $\begin{array}{l}\text { Consumer } \\
\text { Application }\end{array}$ & $\begin{array}{l}\text { Interface } \\
\text { Technology }\end{array}$ \\
\hline 1 & $\begin{array}{l}\text { Master Pegawai } \\
\text { (HCIS) }\end{array}$ & $\begin{array}{l}\text { Sistem Informsi } \\
\text { Kinerja Pegawai }\end{array}$ & $\begin{array}{l}\text { Database } \\
\text { (View) }\end{array}$ \\
\hline 2 & $\begin{array}{l}\text { Sistem Informsi } \\
\text { Kinerja Pegawai }\end{array}$ & $\begin{array}{l}\text { Master Pegawai } \\
\text { (HCIS) }\end{array}$ & $\begin{array}{l}\text { Database } \\
\text { (View) }\end{array}$ \\
\hline 3 & $\begin{array}{l}\text { Sistem Informsi } \\
\text { Kinerja Pegawai }\end{array}$ & $\begin{array}{l}\text { Talent Pool } \\
\text { System In Intanet } \\
\text { (View) }\end{array}$ & $\begin{array}{l}\text { Web Services } \\
\text { (JSON) }\end{array}$ \\
\hline 4 & $\begin{array}{l}\text { Sistem Informsi } \\
\text { Kinerja Pegawai }\end{array}$ & $\begin{array}{l}\text { Portal Perusahaan } \\
\text { Panan }\end{array}$ \\
\hline
\end{tabular}

\section{KESIMPULAN DAN SARAN}

Hasil perancangan system yang dibahas pada penelitian ini berhasil diimplementasikan menjadi suatu sistem informasi dengan baik pada perusahaan dan sudah dijalankan dalam 1 (satu) tahun periode perencanaan dan penilaian kinerja pegawai perusahaan. Pada tahap awal implementasi terdapat beberapa kendala meliputi bugs pada aplikasi yang ditemukan dan adanya perubahan minor pada tampilan user interface aplikasi untuk memudahkan penggunaan oleh pegawai. Perbaikan sudah dilakukan selama implementasi berlangsung, sehingga pada akhir periode penilaian kinerja pegawai, tujuan perusahaan untuk melakukan penilaian kinerja pegawai secara online yang kemudian akan berkontribusi pada penilaian kinerja organisasi dan perusahaan dapat dilaksanakan. Saat ini system ini akan mulai pergunakan kembali untuk mendukung siklus manajemen kinerja perusahaan pada periode yang akan datang. Beberapa perbaikan dan penyesuaian akan dilakukan untuk memperbaiki kinerja system ini kedepan.

Beberapa kesimpulan yang dapat dihasilkan dari hasil penelitian ini antar lain :

1. Untuk menerapkan target parameter kinerja perusahaan secara nyata kepada target kinerja masing-masing pegawai dapat dilakukan proses penurunan (cascading) parameter kinerja level perusahaan secara top-down sampai ke level unit kerja spesifik perusahaan. Kinerja pegawai dapat menyesuaikan dengan unit kerja masingmasing

2. Parameter kinerja perusahaan dapat mengadopsi konsep Balanced Score Card (BSC). Parameter BSC ini dapat diturunkan

Ridha Hanafi 
dari level perusahaan secara spesifik ke masing-masing pegawai

3. Implementasi manajemen kinerja perusahaan dan pegawai akan lebih mudah, terstruktur dan mudah dimonitor apabila menggunakan aplikasi online yang dapat diakses oleh masing-masing pegawai dan dapat berinteraksi langsung dengan atasannya masing-masing

4. Perancangan sistem informasi kinerja pegawai yang dilakukan pada penelitian ini dapat digunakan sebagai referensi tahapan berikutnya pengembangan sistem khususnya tahapan pemrograman sistem, testing dan integrasi sistem.

Adapun saran-saran yang dapat disampaikan dalam penelitian ini antara lain

1. Sistem Informasi Kinerja perusahaan akan lebih baik apabila terintegrasi dengan master data pegawai perusahaan sehingga menjamin data kepegawaian dan kinerja yang up to date dan valid. Integrasi dengan sistem informasi kompetensi pegawai akan memberikah hasil analisa pengembangan pegawai yang lebih baik dengan adanya analisa Talent Pool

2. Perancangan pada penelitian ini dapat dilanjutkan untuk perancangan sistem yang lebih detail lagi khususnya untuk kepentingan pemrograman sistem, misalnya dengan perancangan class diagram dengan menambahkan desain method dan lainnya. Selain itu juga dapat dilanjutkan dengan desain testing yang akan dilakukan untuk melakukan testing aplikasi.

3. Perlu dikembangkan aplikasi berbasis mobile yang dapat diakses pada smartphone oleh pegawai untuk memudahkan akses dan penggunaan aplikasi, sehingga pegawai dapat menggunakan system dimana saja dan kapan saja baik dalam kondisi online maupun offline

\section{REFERENSI}

Aguinis, Herman. Performance Management, 2014, Pearson Publishing

Pramuhanto, Arief. Performance Management, 2009, Talenta Consulting Publishing.

Pressman, Roger. Software Engineering: A Practitioner's Approach. 2014, McGraw Hill

Griffith, Ricky W. International Business, Global Edition. 1995, Pearson

Schermerhorn Jr, John. Management,. 2011, John Wiley \& Sons

Donnelly, James H. Gibson, James L. Ivancevich, John M. Fundamental of Management. 1998, McGraw Hill

Hersey, Paul. Blanchard, Kenneth. Management of Organizational Behavior. 1995, John Wiley \& Sons

Kaplan, Robert S.Balanced Score Card : Translating Strategy Into Action. 1996, The President and Fellow of Harvard College

Ridha Hanafi 